\title{
Study on Mechanical Properties and Durability of Tuff Stone Powder Concrete
}

\author{
Yao Wang ${ }^{1, \text { a }}$, Xixian $\mathrm{Ji}^{2, \mathrm{~b}}$, Fangyu Tang $^{2, \mathrm{c}}$, Guoqin Chen ${ }^{1, \mathrm{~d}}$, \\ Hengchun Zhang ${ }^{2, ~ e}$ \\ ${ }^{1}$ CSCEC Strait Construction and Development Co., Ltd., Fuzhou, 350000, China \\ ${ }^{2}$ China State Construction Ready Mixed Concrete Fujian Co., Ltd., Fuzhou, 350000, China \\ aemail:544589367@qq.com, bemail:290634171@qq.com, 'email:1143396707@qq.com, \\ demail:1055959311@qq.com, eemail:115076527@qq.com
}

Keywords: Tuff; Concrete; Durability; admixture

\begin{abstract}
In this paper, the mechanical properties and durability of tuff stone powder concrete were systematically studied by comparing the performance of fly ash concrete under the same test conditions. The results showed that under the same age, the mechanical, shrinkage performance, sulfate corrosion resistance and early cracking performance of tuff stone powder concrete were same as fly ash concrete. The test results could provide sufficient technical support for the feasibility of tuff stone powder as concrete admixture.
\end{abstract}

\section{Introduction}

A new inorganic non-metallic mineral resource-tuff, which contains $\mathrm{SiO}_{2}, \mathrm{Al}_{2} \mathrm{O}_{3}, \mathrm{~K}_{2} \mathrm{O}$ and $\mathrm{Na}_{2} \mathrm{O}$ and other major components, as well as $\mathrm{CaO}, \mathrm{MgO}, \mathrm{TiO}_{2}, \mathrm{FeO}$ and $\mathrm{Fe}_{2} \mathrm{O}_{3}$ and other minor components, has a certain chemical activity, such as volcanic ash materials, fly ash and the other [1-2], so that it has the study value of concrete composition material. Currently, the research and achievements of tuff applied to concrete are relatively rare, only Li Zunyun, Zhou Yujuan etc. [3-5] had researched on the mechanical properties and durability of tuff sand concrete, the application technology of tuff stone powder for concrete admixture has none related reports.

In China, tuff resources are mainly distributed in the east, by the China Building Materials Industry Geological Prospecting Center Fujian Corps exploration, Minqing County in Fuzhou, has a tuff mine which reserve about 20 million. Based on the mine resources, after sampling and grinding, the tuff stone powder with good comprehensive properties was prepared. By comparing the properties of fly ash concrete, mechanical properties, shrinkage performance, sulfate corrosion resistance and early cracking performance of tuff stone powder concrete were studied to provide technical support for the application of tuff stone powder admixture in concrete.

\section{Test Raw Materials and Methods}

Test Raw Materials. The cement was P.O42.5 Portland cement produced by Conch Cement Plant, which 3d and 28d compressive strength was 26.7MPa and 46.9MPa. Fly ash was II grade ground fly ash from the Fujian Huaneng Power Plant, which fineness was 15.9\%. Slag was S95 grade slag from Fujian Jin Xinyuan Energy Building Materials Co., Ltd, which specific surface area was $425 \mathrm{~m}^{2} / \mathrm{kg}$, 28d activity index was $103 \%$. Sand from Minhou, mixed by machine-made sand and fine sand with the 6:4 mixing ratio, which fineness modulus was 2.7. Gravel from Minhou, which grade was $5-31.5 \mathrm{~mm}$ continuous. Water reducing agent was polycarboxylate high-performance water reducing agent, which solid content was $20.8 \%$ and water reduction rate was more than the $25 \%$.

Tuff mine from Minqing County of Fujian, after the jaw crusher broken, grinded 15min by the ball mill, the tuff stone powder was obtained with specific surface area of $312.4 \mathrm{~m}^{2} / \mathrm{kg}$. By XRD and XRF phase detection, the mineral composition and chemical composition shown in Fig. 1 and 
Tab. 1. From Fig. 1, it could be seen that the mineral components of tuff are mainly $\mathrm{SiO}_{2}$, $\mathrm{K}_{2} \mathrm{O} \cdot \mathrm{Al}_{2} \mathrm{O}_{3} \cdot 6 \mathrm{SiO}_{2}, \mathrm{NaAlO}_{2} \cdot 3 \mathrm{SiO}_{2}$ and $\mathrm{Al}_{2} \mathrm{Si}_{2} \mathrm{O}_{5}(\mathrm{OH})_{4}$.

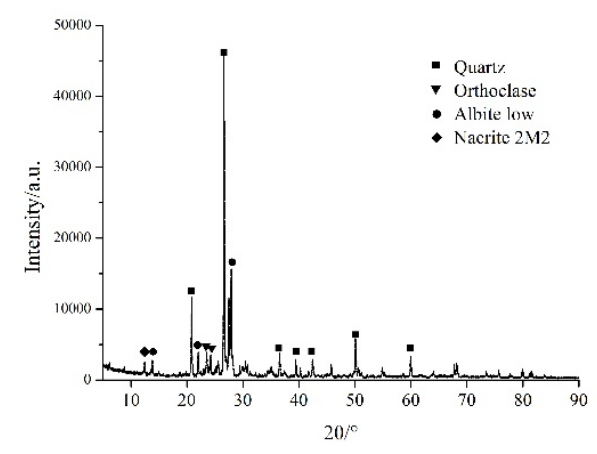

Fig.1 XRD phase analysis of Tuff

Tab.1 Chemical composition of tuff

\begin{tabular}{cccccccccc}
\hline Oxide & $\mathrm{SiO}_{2}$ & $\mathrm{Na}_{2} \mathrm{O}$ & $\mathrm{K}_{2} \mathrm{O}$ & $\mathrm{Al}_{2} \mathrm{O}_{3}$ & $\mathrm{CaO}$ & $\mathrm{Fe}_{2} \mathrm{O}_{3}$ & $\mathrm{MgO}$ & $\mathrm{TiO}_{2}$ & Other \\
\hline Content $/ \%$ & 72.8 & 3.0 & 3.7 & 13.7 & 1.6 & 2.8 & 0.7 & 0.3 & 1.4 \\
\hline
\end{tabular}

Test methods. According GB / T50081 "Mechanical properties test method standards of ordinary concrete" to test the mechanical properties of concrete; According GB / T50082

"Long-term performance and durability test method standards of ordinary concrete" to test concrete shrinkage, early cracking performance.

Early volume shrinkage test method was capillary micro-pressure, and test materials was paste with the same ratio as concrete, which installed in the balloon. The test device schematic diagram shown in Fig.2, that is, with the slurry shrinkage, the balloon filled with slurry in the water will change, then the capillary in the scale tube changes due to water pressure, causing the water level scale to change, at last producing a quantified water level difference. The calculation formula of early volume shrinkage rate $\varepsilon$ as follows (1):

$$
\varepsilon=\frac{\left(v_{i}-v_{0}\right) \times \rho}{m_{1}-m_{0}} \times 100 \%
$$

In: $v_{i}$-I test age's scale value of capillary, $0.001 \mathrm{~mL}$,

$v_{0}$ _-Initial scale value of capillary, $0.001 \mathrm{~mL}$,

$m_{1}$ - Total quality of balloon and sample, $0.1 \mathrm{~g}$,

$m_{0}$-Balloon quality, 0.1g,

$\rho$-Sample density, $\mathrm{g} / \mathrm{cm}^{3}$.

Sulfate corrosion test uses long-term immersion method, the specimen was mortar which removed the coarse aggregate of concrete, which size was $40 \mathrm{~mm} \times 40 \mathrm{~mm} \times 160 \mathrm{~mm}$. After forming $1 \mathrm{~d}$, removed the mold, the specimen cured $7 \mathrm{~d}$ in the $20{ }^{\circ} \mathrm{C}$ water, then started the long-term immersion test. The specimens were immersed in $5 \%$ sodium sulfate solution and fresh water for 30 days, 60 days, 90 days, 120 days and 150 days respectively. After expiration of the age, a group of mortar was removed from the solution and fresh water respectively, which measured the compressive strength, then calculated the compressive corrosion resistance coefficient. The 5\% sodium sulfate solution was changed every 2 weeks. The calculation formula of compression corrosion resistance coefficient $\mathrm{K}$ as follows (2):

$$
\mathrm{K}=\frac{R_{i}}{R_{0}}
$$

In: $\mathrm{K}$ —compression corrosion resistance coefficient, \%,

$R_{i}$ —i test age's compressive strength of specimens immersed in 5\% sodium sulfate solution,

$R_{0}$ — the same test age's compressive strength of specimens immersed in fresh water. 


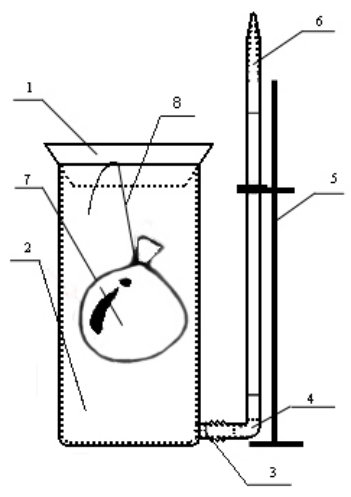

Fig.2 Test device schematic diagram of early volume shrinkage

1- Rubber stopper, 2- Open glass bottle, 3- Outlet, 4- Rubber hoses, 5- Support frame, 6- Scale capillary, 7-Balloon, 8- Rope

\section{Test results and analysis}

Based on the C30 fly ash concrete, the mechanical, early shrinkage, dry shrinkage, sulfate corrosion resistance and early cracking performance of tuff stone powder concrete were studied under the same conditions to provide system technical support for the application of tuff stone powder admixture in concrete. Fly ash and tuff stone powder concrete mix and performance results were shown in Tab. 2.

Tab.2 Mix ratio and work performance of fly ash and tuff stone powder concrete

\begin{tabular}{ccccccccccc}
\hline Number & C & FA & NF & SG & S1 & G & W & P & $\begin{array}{c}\text { Slump } \\
/ \mathrm{mm}\end{array}$ & $\begin{array}{c}\text { Extensibility } \\
/ \mathrm{mm}\end{array}$ \\
\hline CFA & 200 & 70 & $/$ & 80 & 870 & 970 & 165 & 3.8 & 200 & 560 \\
CNF & 200 & $/$ & 70 & 80 & 870 & 970 & 165 & 3.8 & 190 & 480 \\
\hline
\end{tabular}

Mechanical properties. It could be seen that the slump of fly ash concrete and tuff stone powder concrete was similar with the same water reducing agent in Tab.2, but the former fluidity was much better than the latter, the difference was $80 \mathrm{~mm}$. The strength of fly ash concrete was slightly higher than that of tuff stone powder concrete at the same curing age in Fig.2, and the difference was $0.5 \mathrm{MPa}, 2.8 \mathrm{MPa}$ and $3.1 \mathrm{MPa}$ at $7 \mathrm{~d}$, 28d and $56 \mathrm{~d}$ curing age respectively, which showed that the strength of tuff stone powder concrete and fly ash concrete was equivalent.

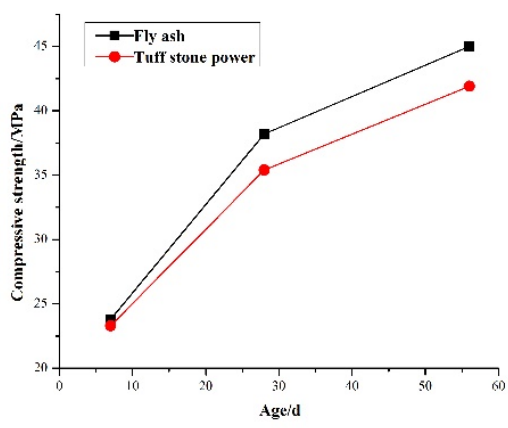

Fig.3 The curve between age and compressive strength of concrete

Shrinkage performance. The early volumetric shrinkage and drying shrinkage test results of fly ash and tuff stone powder concrete were shown in Fig.4. As shown in Fig.4 (a), it could be seen that the $7 \mathrm{~d}$ volume shrinkage of fly ash concrete was $9.6 \times 10^{-6}$, and the volume shrinkage of tuff stone powder concrete is $7.0 \times 10^{-6}$, the former was $37 \%$ higher than the latter, indicating that the early shrinkage of tuff stone powder concrete was much smaller than fly ash concrete. As shown in Fig.4 (b), it could be seen that the drying shrinkage rate of fly ash and tuff stone powder concrete was similar at the same age, but it still could be seen that the drying shrinkage of tuff stone powder 
concrete was slightly lower than that of fly ash concrete before 21d age, and slightly higher than that of fly ash concrete after $21 \mathrm{~d}$ age. The reason may be that the early shrinkage deformation of tuff stone powder concrete was smaller than that of fly ash concrete at the same time, which compensated the deformation of tuff stone powder concrete in early drying shrinkage, resulting in the slightly smaller phenomenon of early drying shrinkage of tuff stone powder concrete.

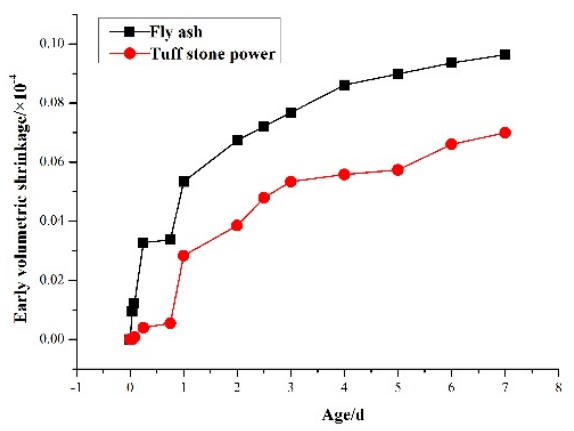

(a) Early volumetric shrinkage

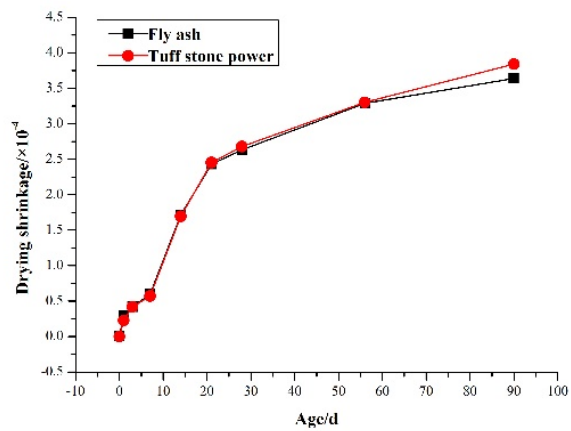

(b) Drying shrinkage

Fig.4 The Shrinkage performance of fly ash and tuff stone powder concrete

Sulfate corrosion resistance. The time-varying curve of compression corrosion resistance coefficient of fly ash and tuff stone powder concrete in $5 \%$ sulfate solution and fresh water were shown in Fig.5. As shown in Fig.5, it could be seen that with the increase of soaking time, the corrosion resistance coefficient of fly ash and tuff stone powder concrete both behaved the trend that decreased at initial stage ( $0 \sim 30$ days), increased at middle stage (31 90 days), then decreased at later stage (91 150 days) ). The compression corrosion resistance coefficient of fly ash and tuff stone powder were similar, indicated that the resistance to sulfate attack of tuff stone powder was equivalent to that of fly ash.

The reason may be that at the early stage of corrosion, as the incorporation of fly ash or tuff stone powder, it would be relatively reduce $\mathrm{C}_{3} \mathrm{~A}, \mathrm{C}_{3} \mathrm{~S}$ and other mineral content, thereby reduce the hydration products such as calcium hydroxide, calcium aluminate hydrate and other products, then reducing the formation of $\mathrm{AFt}$, and resulting in the corrosion resistance was not obvious. With the increase of corrosion time, the production of AFt or gypsum gradually increases, filling the concrete voids, and increasing the density of concrete, making the anti-corrosion ability obviously enhanced. At the later stage of corrosion, continuous formation of AFt in the concrete forms a great internal stress, easily leading to the formation and expansion of internal cracks, resulting in decreased corrosion resistance.

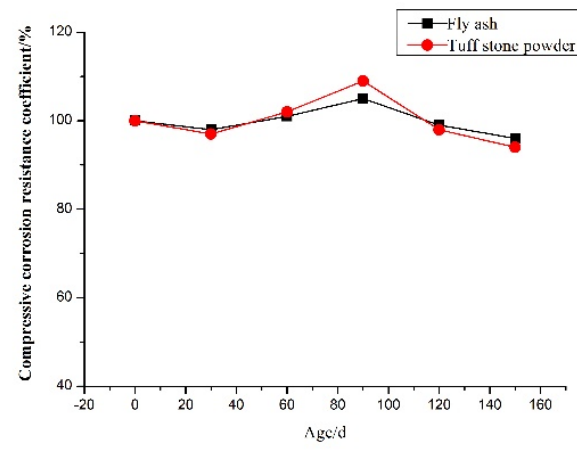

Fig.5 The time-varying curve of compression corrosion resistance coefficient of fly ash and tuff stone powder concrete

Early cracking performance. The test results of early cracking performance of fly ash and tuff stone powder concrete were shown in Tab.3. The average cracking area on per crack in fly ash concrete was smaller than that of tuff stone powder concrete, the cracks number on unit area was more than that of tuff stone powder concrete, but the total cracking area on unit area were similar, according GB50164 "concrete quality control standards" to classification, both cracking 
performance were L-IV level, indicated that the crack resistance performance of fly ash and tuff stone powder concrete was quite.

Tab.3 The early cracking performance of fly ash and tuff stone powder concrete

\begin{tabular}{cccc}
\hline Number & $\begin{array}{c}\text { Average cracking area on per } \\
\text { crack }\left(\mathrm{mm}^{2} / \mathrm{per}\right)\end{array}$ & $\begin{array}{c}\text { Cracks number on unit } \\
\text { area }\left(\mathrm{per} / \mathrm{m}^{2}\right)\end{array}$ & $\begin{array}{c}\text { Total cracking area on } \\
\text { unit area }\left(\mathrm{mm}^{2} / \mathrm{m}^{2}\right)\end{array}$ \\
\hline CFA & 11.2 & 13.5 & 165 \\
CNF & 14.0 & 11.4 & 160 \\
\hline
\end{tabular}

\section{Conclusion}

The mechanical, shrinkage performance, sulfate corrosion resistance and early cracking performance of tuff stone powder and fly ash concrete were quite, indicated that tuff stone powder could be used as concrete admixture.

As a new inorganic nonmetallic material, the application of tuff has a wide prospect. If it is developed into building materials, tuff can not only give full play to its commercial value, but also become the hotspot and development trend of green concrete technology, so its application study is very meaningful.

\section{References}

[1] Shichun Mu. Physical and chemical properties of tuff and it development and application [J]. Mineral resources, 2000(9)17-19.

[2] Shichun Mu. Preliminary study on development and application of tuff [J]. Non-Metallic Mines, 2000(23)18-21.

[3] Zunyun Li, Yujuan Zhou, Mingqiang Qin, Yanhong Sun. Study on chloride resistance durability of marine concrete with tuff machine-made sand [J].Bulletin of the Chinese ceramic society, 2015(34)955-959.

[4] Yujuan Zhou, Sanan Chen, Wen Zhan, Mingqiang Qin, Wenbing Xu. Study on mechanics and durability of tuff machine-made sand concrete for box girder [J].Construction technology, 2015(44)16-18.

[5] Qing Tang. Comparative study on mechanical properties of concrete with limestone and tuff machine-made sand [J].China Water Transport, 2015(15)316-318. 